\title{
Words for English-Language Learners
}

\section{Andrew Biemiller}

It is well-established that vocabulary is the strongest predictor of reading comprehension from grades 2 or 3 on. In this article, I argue (a) that English vocabulary is acquired in a similar sequence by native-English speakers and English-language learners; and (b) that it is possible to identify words that both lower-vocabulary English-speakers and English-language learners need to acquire. At least one published listing of these needed word meanings is available.

Il est bien établi que le vocabulaire est la meilleure variable explicative de la compréhension de lecture à partir de la $2^{e}$ et $3^{e}$ année. Dans cet article, j'affirme (a) que la séquence d'acquisition du vocabulaire en anglais est semblable chez les locuteurs natifs d'anglais et les apprenants en ALS et (b) qu'il est possible d'identifier les mots que doivent acquérir les locuteurs natifs d'anglais et les apprenants en ALS qui ont un vocabulaire moins développé. Il existe au moins une liste publiée de ces mots.

By kindergarten, vocabulary is well-established as the most important predictor of reading comprehension from grade 2 or 3 on (Scarborough, 2001; Stahl \& Nagy, 2006; Storch \& Whitehurst, 2002). Oral vocabulary in grade 1 is a good predictor of reading comprehension in grade 11 (Cunningham \& Stanovich, 1997). By grade 3, there are substantially more words that most children can read than there are word meanings that children understand (Biemiller, 2005).

Between grades 2 and 6, the percentage of a list of grade 2-12 words that average children could read correctly increased from $44 \%$ (grade 2) to $84 \%$ (grade 6). However, knowledge of these words' meanings in context increased much less, from $37 \%$ to $53 \%$.

Thus by grade 3 , the greatest limitation for reading comprehension-and hence academic achievement-is a limited vocabulary. By this time, a quarter of English-speaking children lag one to three years behind average in vocabulary, and there is no evidence that thereafter they catch up. At best, they may not fall further behind once they have mastered reading mechanics (Biemiller \& Slonim, 2001).

\section{The Vocabulary Sequence for Native English Speakers}

Biemiller and Slonim (2001) and Biemiller (2005) summarize the evidence for the sequence used to acquire word meanings. Their data refer to children who spoke English from birth. First, the order of how well word meanings 
are known is correlated from one grade to the next. Second, the meanings known by a child are determined by the size of his or her vocabulary rather than age. Thus if a child in grade 2 , a child in grade 4 , and a child in grade 6 all know about 8,000 meanings, the grade 4 average, it is likely that they know largely the same meanings.

Figure 1 illustrates this point. Root word meanings were sampled from Dale and O'Rourke's (1981) dictionary of elementary and high school levels. The meanings were grouped in deciles from the best-known $10 \%$ to the leastknown $10 \%$ in our study of representative English-speaking children from kindergarten to grade 6 . The children were grouped according to the number of meanings they knew, ranging from the most (60-65\%) of all meanings tested to the least (1-9\%). Children who knew many words understood all or most of the word meanings from the first five groups of words. Those knowing few meanings understood only about $40 \%$ of the best-known $10 \%$ of the words, and fewer or none of the rest.

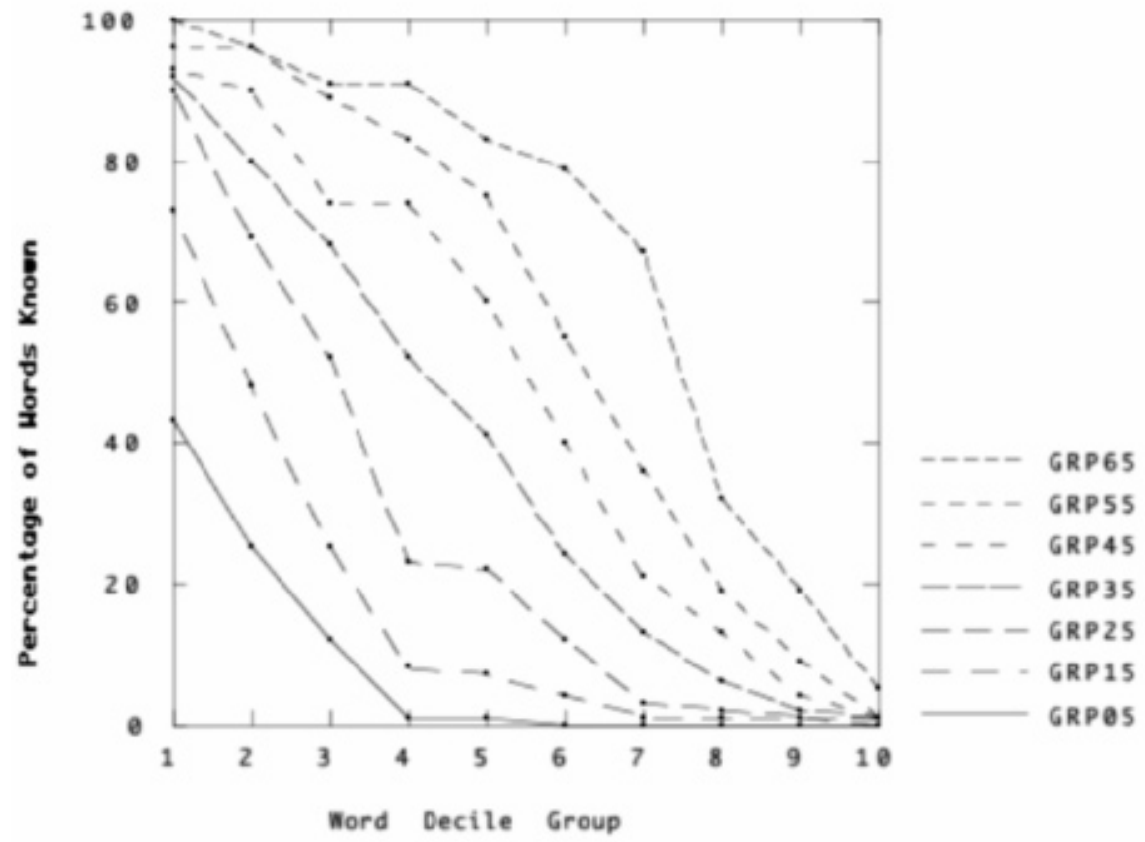

Figure 1. Words from various difficulty levels by children with varied sizes of vocabulary.

(This figure has been taken from Biemiller and Slonim (2001) by permission of the American Psychological Association.) 
The practical implication of the graph shown in Figure 1 and data found in the norms of any standardized vocabulary test is that at any point in their development, children are acquiring word meanings from a limited pool of possible meanings, which indicates that it should be possible to determine meanings that are useful for instruction of children at this point.

\section{Evidence that Second-Language Learners Acquire English in a Similar Sequence}

Shortly after our Biemiller and Slonim (2001) study on the sequence of acquiring words was published, we administered the same 117 words to a population of mainly English-as-a-second-language students in grade $5(N=49)$ and grade $6(N=31)$ in an inner-city school in a large Canadian city. These children came from diverse ethnic groups and countries including China, India, Pakistan, and Egypt. Only 5\% of all children at this school were native speakers of English who spoke English at home.

My colleagues and I contrasted these children's knowledge of meanings sampled from Living Word Vocabulary grade levels 2-12 to knowledge of meanings from our earlier study with a sample of representative (range of socioeconomic status) English-speaking children from a smaller city in central Canada.

Overall, the English-learner children knew an average of 30\% of these words in grade 5 and $34 \%$ in grade 6 . The English-speaking children averaged $53 \%$ in grade 5 and $54 \%$ in grade 6 . Grade 2 children in the Englishspeaking group averaged knowledge of $37 \%$ of these words (Table 1). The correlations between word knowledge (word means) for the second-language and native speakers is in the range of $r=.79$ to .83 (Table 2). Correlations were about the same for the grades 5 and 6 English-learner children and grade 2 native-English speakers in ( $r=.82$ to .84$)$. Although not as strong as the correlations across grades in the same language group, these correlations clearly indicate that words are being learned in a similar order.

Except for word meanings known by few children from first- or secondlanguage groups (e.g., reformation, discord) or words known by most children from both backgrounds (e.g., math, listen), the second-language children were less likely to know meanings. The magnitude of difference appears to reflect possibilities for encountering a word; thus meanings for words such as transit, parcel, and through differed moderately by $20-40 \%$. Meanings that differed more than $40 \%$ such as those for envelop, justice, and loop, were less likely to be encountered by the second-language students.

\section{Establishing Words Worth Teaching}

The existence of a sequence in the acquisition of word meanings makes it possible to identify word meanings appropriate for children with varied vo- 
Table 1

Means for English Speakers and English Learners by Grade

\begin{tabular}{lccc}
\hline Language Group & Gr2 & Gr 5 & Gr 6 \\
\hline No of Eng.-Speakers ${ }^{1}$ & 25 & 24 & 20 \\
Eng.-Speakers & $37 \%(32 \%)$ & $54 \%(34 \%)$ & $58 \%(33 \%)$ \\
No of Eng.-Learners & & 49 & 31 \\
Eng.-Learners & & $30 \%(29 \%)$ & $34 \%(29 \%)$ \\
\hline
\end{tabular}

Note 1. Two samples of English-speakers who each had half of the 117 words included.

Table 2

Correlations Across Word Meanings for

English-Speakers and English Learners

\begin{tabular}{|c|c|c|c|c|c|}
\hline \multirow{2}{*}{$\begin{array}{l}\text { Language } \\
\text { and Grade }\end{array}$} & \multicolumn{2}{|c|}{ Eng.-Learners } & \multicolumn{3}{|c|}{ Eng.-Speakers } \\
\hline & gr. 5 & gr. 6 & gr. 2 & gr. 5 & gr. 6 \\
\hline Eng.-Learners gr. 5 & - & & & & \\
\hline Eng.-Learners gr. 6 & .96 & - & & & \\
\hline Eng.-Speakers gr. 2 & .84 & .82 & - & & \\
\hline Eng.-Speakers gr. 5 & .83 & .83 & .90 & - & \\
\hline Eng.-Speakers gr. 6 & .79 & .80 & .86 & .93 & - \\
\hline
\end{tabular}

cabulary sizes around the primary and upper-elementary grades. Some word meanings most children know, some are useful to learn, and some are best learned at a later time. In general, I prefer to focus on the meanings needed by those with below-average vocabulary. (Choices of meanings to teach might be different for a group of children with mostly above-average vocabulary.) I do not try to establish meanings for each grade because children vary in their vocabulary sizes. Instead, I seek to determine meanings that might best be learned during the primary years and another group of meanings that may best be learned in the upper-elementary grades.

To find word meanings for the primary grades, I look for root word meanings known by $40-80 \%$ of children at the end of grade 2 (Biemiller, 2009). These $40-80 \%$ meanings are usually known by those with relatively large vocabularies at the end of grade 2 . To find these $40-80 \%$ meanings, my colleagues and I tested 3,000 root word meanings, about half the root word meanings at grade levels 4 and 6 as reported in Dale and O'Rourke's Living Word Vocabulary (1981). ${ }^{1}$ We tested representative English-speaking children 
in an Ontario city. We rated another 3,000 meanings as easy, probably known by more than $80 \%$ at the end of grade 2 ; worth teaching, probably known by $40-80 \%$; or difficult, probably known by fewer than $40 \%$. After testing a sample of 100 of these rated words, we found that $80 \%$ of the meanings tested at the rated levels. In addition, we found some words in Living Word Vocabulary word meanings at grade levels 8 and 10 that testing indicated should be addressed during the primary period. Ultimately, we identified some 1,600 high-priority word meanings that should be taught or learned in the primary grades. All word meanings tested are described and illustrated in Words Worth Teaching (Beimiller, 2009).

In the same way, we tested another 3,000 root word meanings and rated 2,000 meanings for upper-grade instruction. This time, we looked for meanings known by $40-80 \%$ of students at the end of grade 6 . These meanings were mainly drawn from Dale and O'Rourke's (1981) Living Word Vocabulary and listed at grade levels 8 or 10. We included some meanings from Living Word that proved difficult for grade 2 children. Ultimately, we identified 2,900 high-priority word meanings that should be taught or drawn to students' attention in grades 3-6. ${ }^{2}$

Suggestions for instruction or students' attention to these priority meanings are presented in Words Worth Teaching (Biemiller, 2009) as well as in books by Beck, McKeown, and Kucan $(2002,2008)$, Blachowicz and Fisher (2009), Graves (2006), and Stahl and Nagy (2006). It is necessary to teach these priority meanings in the primary grades, as children are unlikely to encounter many of them in books read in grade 1 or 2 . In the upper-elementary grades, students can take greater responsibility for acquiring needed meanings if the words are drawn to their attention and later assessed. For English-language learners, possibly a number of meanings among the easy word meanings in Words Worth Teaching should be addressed for primary-grade students. Similarly, some of the primary meanings (priority T2 in Words Worth Teaching) may need to be taught or addressed with upper-elementary English-language learners. As noted above, a sample of grades 5 and 6 English-language learners, children who were not speaking English at home, averaged about the same vocabulary as representative grade 2 native English-speaking children.

\section{Summary}

Children tend to acquire word meanings in English in similar sequences. This progression is true for English-language learners as well as for children raised speaking English. Because meanings are acquired in a predictable order, it is possible to identify them to teach to those who acquire vocabulary slowly. One available listing of high-priority word meanings reports some 1,600 meanings for primary-grade children and another 2,900 meanings for upper-elementary children (Biemiller, 2009). This listing is helpful for Eng- 
lish-language learners as well as for lower-vocabulary English-speaking children. However, it may be necessary to teach English-learners some words that are generally known by children who speak English at home.

\section{Notes}

1 The Living Word Vocabulary includes some 44,000 word meanings, of which 30,000 were reported known in high school or earlier. The grade levels assigned to meanings were based on multiple-choice tests administered at grades $4,6,8,10,12$, and college levels. No testing was done below grade 4 because reading problems would interfere with results. Words were assigned to grade levels at which 50-70\% of words were passed (adjusted for guessing on three alternative tests). Biemiller and Slonim (2001) established that meanings known by more than $70 \%$ of grade 4 children could be considered grade 2 -level meanings or earlier. In fact, these meanings were known by an average of $80 \%$ of the children in our sample at grade 2 .

${ }^{2}$ Details for creating the lists of priority words for primary and upper-elementary students are provided in Biemiller (2009).

\section{The Author}

Andrew Biemiller taught at the University of Toronto for 36 years. He was responsible for the teacher education program at the Institute of Child Study for 15 years. His recent research concerns what word meanings are acquired, the order of meanings acquired, and effective methods of teaching word meanings. He recently published Words Worth Teaching (SRA/McGraw-Hill), which summarizes this work.

\section{References}

Beck, I.L., McKeown, M.G., \& Kucan, L. (2002). Bringing words to life: Robust vocabulary instruction. New York: Guilford Press.

Beck, I.L., McKeown, M.G., \& Kucan, L. (2008). Creating robust vocabulary: Frequently asked questions and extended examples. New York: Guilford Press.

Biemiller, A. (2005). Size and sequence in vocabulary development: Implications for choosing words for primary grade vocabulary instruction. In E.H. Hiebert \& M.L. Kamil (Eds.), Teaching and learning vocabulary: Bringing research to practice (pp. 223-242). Mahwah, NJ: Erlbaum.

Biemiller, A. (2009). Words worth teaching: Closing the vocabulary gap. Columbus, $\mathrm{OH}$ : SRA/McGraw-Hill.

Biemiller, A., \& Slonim, N. (2001). Estimating root word vocabulary growth in normative and advantaged populations: Evidence for a common sequence of vocabulary acquisition. Journal of Educational Psychology, 93, 498-520.

Blachowicz, C., \& Fisher, P.J. (2009). Teaching vocabulary in all classrooms (4th ed.). Boston, MA: Allyn \& Bacon.

Cunningham, A.E., \& Stanovich, K.E. (1997). Early reading acquisition and its relation to reading experience and ability 10 years later. Developmental Psychology, 33, 934-945.

Dale, E., \& O'Rourke, J. (1981). The living word vocabulary. Chicago, IL: World Book/Childcraft International.

Graves, M.F. (2006). The vocabulary book: Learning and instruction. New York: Teachers' College Press.

Scarborough, H.S. (2001). Connecting early language and literacy to later reading (dis)abilities: Evidence, theory, and practice. In S.B. Neuman \& D.K. Dickinson (Eds.), Handbook of early literacy research (pp. 97-110). New York: Guilford Press.

Stahl, S.A., \& Nagy, W.E. (2006). Teaching word meanings. Mahwah, NJ: Erlbaum.

Storch, S.A., \& Whitehurst, G J. (2002). Oral language and code-related precursors to reading: Evidence from a longitudinal structural model. Developmental Psychology, 38, 934-947. 